\title{
Antimycotic activity of low polar petroleum ether and interpolar methanolic young leaf extracts of Solanum nigrum L.
}

\author{
Shivakumar Singh $\mathbf{P}$ and Vidyasagar $\mathbf{G M}^{*}$ \\ Medicinal Plants and Microbiology Research Laboratory, Department of Post-Graduate Studies and \\ Research in Botany, Gulbarga University, Gulbarga - 585 106, Karnataka, India.
}

Correspondent author: gm.vidyasagar@rediffmail.com

\begin{abstract}
Antimycotic activity of Petroleum ether and $98 \%$ methanolic young leaf soxhlet extract of Solanum nigrum (Solanaceae) was evaluated against dermatophytic fungi namely, Trichophyton rubrum, Trichophyton tonsurans, Trichophyton mentagrophytes, Microsporium gypseum, Candida albicans, and bacteria like, Staphylococcus aureus, Psudomonas aeruginosa, Bacillus subtilis, Escherichia coli. The maximum activity was observed in interpolar methanolic extract when compared to low polar petroleum ether extract. The minimum inhibitory concentration, minimum fungicidal concentration and minimum bactericidal concentration were determined against all the test strains. This study provides a basis for the isolation and purification of anti-dermatophytic compounds from the young leaves of $S$. nigrum.
\end{abstract}

Key words: Antimycotic activity, 98\% methanolic young leaf extract, Solanum nigrum, MIC, MFC, MBC.

\section{Introduction}

In recent years, plant secondary metabolites (phytochemicals) have been extensively investigated as a source of medical agents (Krishnaraju AV et al., 2005). Thus, it is anticipated that phytochemicals with adequate antibacterial efficacy will be used for the treatment of bacterial infections (Balandrin MF et al., 1985). The Greek physician, Galen (AD129-200) devised the first pharmacopoeia describing the appearance, properties and use of many plants. Approximately $20 \%$ of the plants in the world are found to have pharmacological or biological activities (Suffrendini JB et al., 2004). The plants having capacity to produce a large number of secondary metabolites (Evans JS 1986), which are divided into Chemotherapeutic, bacteriostatic, bactericidal and antimicrobial agent (Purohit SS, and Mathur SK 1999).

The chemical constituent of plants plays an important role in modern medicine after profiling against different biological activities. Antibiotics brought revolution to control pathogenic diseases and fungal infections. But, these synthetic drugs are out of reach to millions of people. People who live in remote places mostly depend on traditional healers 
(Bhattacharjee SK 2001). About three quarters of world population are estimated to be dependent mainly on plants drugs (Jamil A et al., 2007). Medicinal plants possess a variety of phytochemical constituents, which cast a definite physiological action on human body. Some of these chemicals are toxic and may lead to death (Sheeba E 2010).

A large number of plants have been reported by researchers and practitioners of traditional medicine to be useful in the treatment of skin diseases (Miranda 1976, Berlin B et al., 1993). Fungi that infect the skin, nails, and hair, are generally called as "ringworm" or "tinea," and are classified as dermatophytes. Three important genera that are closely related botanically are Microsporum, Trichophyton, and Epidermophyton. The genus Microsporum is the most frequent cause of ringworm of the scalp and may give rise to ringworm in other parts of the body. Trichophyton causes ringworm of the scalp, beard, and other areas of the skin and nails. Epidermophyton is largely responsible for ringworm of the skin, hand and feet and appears as interlacing threads in the skin, but does not invade the hair (Rippon JW 1982). Candida spp. have been reported to be commensal fungi commonly found in the gastrointestinal tract, mouth, and vagina; they become pathogenic only when natural defence mechanism fails (Grabue GE 1994).

The plant Solanum nigrum belongs to Family Solanaceae. The family consists of 90 genera and approximately 2000-3000 species. In this family, Solanum constitutes the largest and the most complex genus and it consists of more than 1500 species, many of which are also economically important throughout their cosmopolitan distribution. The generic name Solanum is considered to be derived from the Latin "Solamen" to refer to the quieting or sedative effects associated with many species (Edmonds JM and Chweya JA 1997). It is commonly known as, 'Black nightshade'. $S$. nigrum elaborated a wide spectrum of medicinal properties such as anticancer, antioxidant (Al-Qirim T et al., 2008), neuroprotective(Jainu M and Devi CSS 2005), liver disorders, chronic skin ailments, inflammatory conditions, painful periods, fevers, diarrhoea, eye diseases, hydrophobia (Kritikar KR and Basu BD 1935), antimicrobial, and antipyretic properties. S. nigrum has been used as the important ingredient for herbal formulations in India, namely Liv. 52 mainly used for treating liver diseases (Ikeda T et al., 1992). S. nigrum seed extract exhibited selective antifungal activity, against $P$. nicotianae (Sashikumar JM et al., 2003).

The authors have documented and published (Shivakumar Singh P and Vidyasagar GM 2013) antidermatophytic plants from Hyderabad Karnataka region, however, the pharmacological work reported on these plants is limited. Therefore the present work was carried out.

\section{Materials and methods}

Collection of plant material and extraction of plant material by soxhlet apparatus: The young leaves of Solanum nigrum were collected in sterile bags from different places of Gulbarga University and identified with the help of Voucher specimen (HGUG-890) deposited in the herbarium centre, Department of Botany, Gulbarga University, Karnataka, India. The collected plant materials were initially rinsed with distilled water to remove soil and other contaminants and shade dried on paper towel at $37 \pm 2^{\circ} \mathrm{C}$ in the laboratory for a week. 
The dried samples were ground in a grinder. $25 \mathrm{~g}$ of shade dried powder was weighed and extracted successively with petroleum ether and interpolar methanol in soxhlet extractor for $48 \mathrm{~h}$. The extracts were concentrated under reduced pressure and stored at $4^{0} \mathrm{C}$ in airtight bottles for further use.

Test fungi and bacteria: Five fungal culture strains, Trichophyton rubrum, Trichophyton tonsurans, Trichophyton mentagrophytes, Microsporum gypseum, Candida albicans and five bacterial strains, Bacillus subtilis, Staphylococcus aureus, Escherichia coli, Pseudomonas aeruginosa obtained from M.R. medical college, Gulbarga, Karnataka, India were used in the present study.

Agar-well diffusion method (Magaldi $\mathrm{S}$ et al., 2004): 15 to $20 \mathrm{ml}$ of potato dextrose agar medium was poured in the sterilized petri dishes and allowed to solidify. Fungal lawn was prepared using 5 days old culture strains. The fungal strains were suspended in a saline solution $(0.85 \% \mathrm{NaCl})$ and adjusted to a turbidity of $0.5 \mathrm{Mac}$ Farland standards (108 $\mathrm{CFU} / \mathrm{ml}) .1 \mathrm{ml}$ of fungal strain was spread over the medium using a sterilized glass spreader. Using flamed sterile borer, wells of $4 \mathrm{~mm}$ diameter were punctured in the culture medium and required concentrations of serially diluted extract $(0.62,1.25,2.5,5,10,20$ and $40 \mathrm{mg} / \mathrm{ml})$ was added to the $20 \mu \mathrm{l}$ to each wells. The plates thus prepared were left for diffusion of extracts into media for one hour in the refrigerator and then incubated at $37^{\circ} \mathrm{C}$. After incubation for $48 \mathrm{~h}$, the plates were observed for zone of inhibition. Diameter zone of inhibition was measured and expressed in millimetres. Dimethyl formamide (DMF) was used as a negative control. The experiments were conducted in triplicates. The same method was followed for testing antibacterial activity using nutrient agar medium incubated at $37^{\circ} \mathrm{C}$ for $18 \mathrm{~h}$.

\section{Minimum Inhibitory Concentration (NCCLS 1997)}

One $\mathrm{ml}$ of sterile liquid Sabouraud medium was added to 11 sterile capped tubes, $1 \mathrm{ml}$ of each solvent extracts suspension was added to tube 1 . The contents were mixed and $1 \mathrm{ml}$ was transferred to tube 2. This serial dilution was repeated through to tube nine and $1 \mathrm{ml}$ was discarded from tube 9. Fifty $\mu \mathrm{l}$ of inoculum was added to tubes 1-10 and the contents were mixed. Medium control (no inoculum and no drug) and inoculum control (no drug) tubes were prepared. The final concentrations of each plant solvent extracts ranged from $05 \mathrm{mg} / \mathrm{ml}$ to $0.02 \mathrm{mg} / \mathrm{ml}$. The tubes were incubated at $30^{\circ} \mathrm{C}$ for $96 \mathrm{~h}$. The fungal growth in each tube was evaluated visually depending up on the turbidity in the tubes. MIC was defined as the drug concentration at which the turbidity of the medium was the same as the medium control.

$10 \mu 1$ aliquot of cell suspension from the tube without observed growth of dermatophytes was inoculated on to Sabouraud dextrose agar, and Minimum fungicidal concentration (MFC), Minimum bactericidal concentration (MBC) of test compound was determined as the lowest concentration of the agent at which no colonies were seen after 4 days at $30^{\circ} \mathrm{C}$. Triplicate sets were maintained for each experiment. 


\section{Statistical Analysis}

All the experiments were conducted in triplicate unless stated otherwise and statistical analysis of the data was performed by analysis of variance (ANOVA), using STATISTICA 5.5 (Stat Soft Inc, Tulsa, Oklahoma, USA) software. A probability value of difference $p<0.05$ was considered to denote a statistically significance All data were presented as mean values \pm standard deviation (SD).

\section{Results and discussion}

The preliminary phytochemical analysis of pet ether and interpolar methanolic young leaf extracts of $S$. nigrum was carried out by adopting standard methods (Horborne JB 1998). The results represented in table-1 reveals the presence of phytochemicals such as, alkaloids, flavonoids, phenols, triterpenoids, glycosides, steroids and tainns. The interpolar methanolic extract shows strong positive response to flavonoids and phenols, moderate response to saponins and steroids, whereas petroleum ether extract showed strong positive response to alkaloids and moderate response to phenol, flavonoids, triterpenoids and glycosides.

The antimycotic studies was carried out against five fungal and five bacterial strains to determine the effect of petroleum ether and $98 \%$ methanolic young leaf extracts of $S$. nigrum. The interpolar methanolic extract exhibited an effective antidermatophytic activity as compared to low polar petroleum ether extract. The maximum antidermatophytic activity was observed against T. rubrum $(16.66 \pm 0.57 \mathrm{~mm})$, followed by M. gypseum $(16.00 \pm 0.00 \mathrm{~mm})$ $T$. mentagrophytes $(12.66 \pm 1.52 \mathrm{~mm}), C$. albicans $(12.33 \pm 0.57 \mathrm{~mm})$ and $T$. tonsurans (11.66 \pm 1.52 ). Maximum antibacterial activity of $21.00 \pm 0.00 \mathrm{~mm}$ was observed in $S$. aureus followed by $B$. subtilis $(18.66 \pm 1.15 \mathrm{~mm}), E$ coli $(17.00 \pm 0.00 \mathrm{~mm})$ and $P$. aeruginosa $(17.33 \pm 1.15 \mathrm{~mm})$. The zone of inhibition was found to be concentration dependent.

Ketoconazole and streptomycin sulphate used as positive controls at conc. $2 \mathrm{mg} / \mathrm{ml}$ against fungi and bacteria, showed $24.00 \pm 0.00$ to $26.33 \pm 1.15 \mathrm{~mm}$ and $26.00 \pm 0.00$ to $29.33 \pm 0.57 \mathrm{~mm}$ inhibition zone, respectively. The negative control (DMF) was showed no inhibition against all the tested fungal and bacterial strains.

The MIC value recorded against $T t, C a$ and $P a$ was $0.15 \mathrm{mg}^{-1}$, similarly, the MFC value against $T t, C a$ was $0.3 \mathrm{mg}^{-1}$. While $0.3 \mathrm{mg}^{-1} \mathrm{MBC}$ value recorded against all the tested bacteria (Figure 1, $2 \& 3$ ).

Table- 3 shows the presence of flavonoids, phenols and tannins in methanolic extract. The earlier reports on phytochemical screening of this species showed positive response to alkaloid, flavonols, flavones, flavanols, saponin, flavonoids and steroids tests(Amir M and Kumar S 2004). Some of the alkaloids like, soladunalinidine, solasonine and solamargine have been isolated from leaf of Solanum species (Juneja D et al., 2007). However, in present studies the Alkaloid tests were weak in colours and the interpolar methanolic extract showed positive to cardiac glycosides. One of the reports from north India (Sweta Prakash and Ashok K. Jain, 2011) showed negative results for cardiac glycosides in aqueous extract. These types of variations may be due to change in climatic and soil conditions. The $98 \%$ methanolic young leaf extract showed effective antimycotic activity and found to have strong positive response to Flavonoids, Phenols and Tannins tests. These compounds may be responsible for antimicrobial activity as reported by Tsuchiya et al., in flavonoids (Tsuchiya $\mathrm{H}$ et al., 1996), Mason and Wasserman in phenolics and polyphenols (Mason TL et al., 1987), Ya et al., (1988) in tannins (Scortichini M et al., 1991), Scortichini and Pia Rossi (1996) in terpenoids, 
Goren in sesquiterpenes (Goren $\mathrm{N}$ et al., 1996), Barnabas CG, Nagarajan $\mathrm{S}$ in alkaloids, glycosides, steroids (Barnabas CG, Nagarajan S 1988). The present study reveals an effective antimicrobial activity in interpolar methanolic extract. Whereas the previous reports showed that the methanolic extracts are weak against food borne and pathogenic organisms (Muhammad Zubair et al., 2011). These observations may be attributed to the nature of biological active components whose activity can be increased in the successive extraction of interpolar methanol (solvent) extracts.

\section{Conclusion}

The antimycotic activity of $98 \%$ methanolic young leaf extract of S. nigrum may be attributed to the phytochemical constituents like phenol, flavonoids and tannins present in crude extract. The purified components may have even more potency with respect to inhibition of microbes. The work carried out was a basic approach to find out the antimycotic activity in $S$. nigrum. Further study on the purification of individual groups of bioactive interpolar-components can reveal the exact potential of the plant to inhibit skin pathogenic microbes.

\section{Acknowledgement}

Authors are thankful to the UGC for extending financial support and Gulbarga University for providing research facility. 
Table 1- Antimycotic activity of petroleum ether and interpolar methanolic young leaf extracts of Solanum nigrum.

\begin{tabular}{|c|c|c|c|c|c|c|c|c|c|c|}
\hline \multirow{3}{*}{$\begin{array}{c}\text { Selected } \\
\text { medicinal } \\
\text { plants }\end{array}$} & \multirow{3}{*}{$\begin{array}{l}\text { Concent- } \\
\text { rations } \\
\mathrm{mg} / \mathrm{ml}\end{array}$} & \multicolumn{9}{|c|}{ Test organisms \& inhibition of zones in $\mathrm{mm}$} \\
\hline & & \multicolumn{5}{|c|}{ Fungal strains } & \multicolumn{4}{|c|}{ Bacterial strains } \\
\hline & & $T r$ & $T t$ & $T m$ & $M g$ & $\mathrm{Ca}$ & $S a$ & $P a$ & $B s$ & Ec \\
\hline \multicolumn{11}{|l|}{ S. nigrum $\mathrm{L}$. } \\
\hline \multirow[t]{8}{*}{ A } & 40 & $06.00 \pm 1.00$ & $04.66 \pm 0.57$ & $04.33 \pm 0.57$ & $06.33 \pm 0.57$ & $05.00 \pm 1.00$ & $06.33 \pm 1.15$ & $05.33 \pm 0.57$ & $\begin{array}{c}05.33 \pm \\
0.57\end{array}$ & $\begin{array}{c}05.66 \pm \\
0.57\end{array}$ \\
\hline & 20 & $04.00 \pm 00$ & NA & NA & $04.33 \pm 0.57$ & NA & $05.00 \pm 0.0 .00$ & $04.00 \pm 0.00$ & NA & $\begin{array}{c}04.00 \pm \\
1.00\end{array}$ \\
\hline & 10 & NA & NA & NA & NA & NA & $04.66 \pm 0.57$ & NA & NA & NA \\
\hline & & NA & NA & NA & NA & NA & NA & NA & NA & NA \\
\hline & 5 & NA & NA & NA & NA & NA & NA & NA & NA & NA \\
\hline & 2.5 & NA & NA & NA & NA & NA & NA & NA & NA & NA \\
\hline & 1.25 & NA & NA & NA & NA & NA & NA & NA & NA & NA \\
\hline & 0.62 & NA & NA & NA & NA & NA & NA & NA & NA & NA \\
\hline \multirow[t]{7}{*}{ B } & 40 & $\begin{array}{c}16.66 \pm \\
0.57\end{array}$ & $\begin{array}{c}11.66 \pm \\
1.52\end{array}$ & $\begin{array}{c}12.66 \pm \\
1.52\end{array}$ & $\begin{array}{c}16.00 \pm \\
0.00\end{array}$ & $\begin{array}{c}12.33 \pm \\
0.57\end{array}$ & $\begin{array}{c}21.00 \pm \\
0.00\end{array}$ & $\begin{array}{c}17.33 \pm \\
1.15\end{array}$ & $\begin{array}{c}18.66 \pm \\
1.15\end{array}$ & $\begin{array}{c}17.00 \pm \\
0.00\end{array}$ \\
\hline & 20 & $\begin{array}{c}14.66 \pm \\
1.52\end{array}$ & $\begin{array}{c}10.33 \pm \\
0.57\end{array}$ & $\begin{array}{c}11.66 \pm \\
0.57\end{array}$ & $\begin{array}{c}15.33 \pm \\
1.15\end{array}$ & $\begin{array}{c}11.33 \pm \\
1.15\end{array}$ & $\begin{array}{c}16.66 \pm \\
1.52\end{array}$ & $\begin{array}{c}16.00 \pm \\
0.00\end{array}$ & $\begin{array}{c}16.66 \pm \\
0.57\end{array}$ & $\begin{array}{c}15.33 \pm \\
0.57\end{array}$ \\
\hline & 10 & $\begin{array}{c}11.33 \pm \\
0.57\end{array}$ & $\begin{array}{c}08.33 \pm \\
0.57\end{array}$ & $\begin{array}{c}09.00 \pm \\
0.00\end{array}$ & $\begin{array}{c}13.33 \pm \\
0.57\end{array}$ & $\begin{array}{c}08.33 \pm \\
0.57\end{array}$ & $\begin{array}{c}14.66 \pm \\
1.15\end{array}$ & $\begin{array}{c}15.33 \pm \\
0.57\end{array}$ & $\begin{array}{c}14.00 \pm \\
0.00\end{array}$ & $\begin{array}{c}13.33 \pm \\
1.15\end{array}$ \\
\hline & 5 & $\begin{array}{c}09.00 \pm \\
0.00\end{array}$ & $\begin{array}{c}06.00 \pm \\
0.00\end{array}$ & $\begin{array}{c}08.33 \pm \\
0.57\end{array}$ & $\begin{array}{c}11.33 \pm \\
1.15\end{array}$ & $\begin{array}{c}07.33 \pm \\
0.57\end{array}$ & $\begin{array}{c}13.00 \pm \\
0.00\end{array}$ & $\begin{array}{c}13.33 \pm \\
1.15\end{array}$ & $\begin{array}{c}13.33 \pm \\
0.57\end{array}$ & $\begin{array}{c}12.00 \pm \\
0.00\end{array}$ \\
\hline & 2.5 & $\begin{array}{c}08.33 \pm \\
0.57\end{array}$ & $\begin{array}{c}05.33 \pm \\
0.57\end{array}$ & $\begin{array}{c}06.33 \pm \\
1.15 \\
\end{array}$ & $\begin{array}{c}09.66 \pm \\
0.57\end{array}$ & $\begin{array}{c}05.33 \pm \\
1.15 \\
\end{array}$ & $\begin{array}{c}12.33 \pm \\
0.57\end{array}$ & $\begin{array}{c}12.66 \pm \\
0.57\end{array}$ & $\begin{array}{c}08.00 \pm \\
0.00\end{array}$ & $\begin{array}{c}10.33 \pm \\
1.15\end{array}$ \\
\hline & 1.25 & $\begin{array}{c}06.33 \pm \\
1.15 \\
\end{array}$ & NA & $\begin{array}{c}05.00 \pm \\
0.00 \\
\end{array}$ & $\begin{array}{c}07.00 \pm \\
0.00 \\
\end{array}$ & $\begin{array}{c}04.33 \pm \\
0.57 \\
\end{array}$ & $\begin{array}{c}10.66 \pm \\
1.15 \\
\end{array}$ & $\begin{array}{c}11.00 \pm \\
0.00 \\
\end{array}$ & $\begin{array}{c}06.33 \pm \\
0.57 \\
\end{array}$ & $\begin{array}{c}09.00 \pm \\
0.00 \\
\end{array}$ \\
\hline & 0.62 & NA & NA & NA & $\begin{array}{c}05.66 \pm \\
1.15\end{array}$ & NA & $\begin{array}{c}08.66 \pm \\
1.52\end{array}$ & $\begin{array}{c}10.33 \pm \\
1.15\end{array}$ & $\begin{array}{c}05.00 \pm \\
0.00\end{array}$ & $\begin{array}{c}08.66 \pm \\
0.57\end{array}$ \\
\hline K & 02 & $\begin{array}{c}24.00 \pm \\
0.57\end{array}$ & $\begin{array}{c}26.33 \pm \\
1.15\end{array}$ & $\begin{array}{c}26.00 \pm \\
1.00\end{array}$ & $\begin{array}{c}24.66 \pm \\
1.52\end{array}$ & $\begin{array}{c}24.00 \pm \\
0.00\end{array}$ & - & - & - & - \\
\hline $\mathbf{S}$ & 02 & - & - & - & - & - & $\begin{array}{c}29.33 \pm \\
0.57\end{array}$ & $\begin{array}{c}28.33 \pm \\
1.15\end{array}$ & $\begin{array}{c}26.00 \pm \\
0.00\end{array}$ & $\begin{array}{c}26.33 \pm \\
1.15\end{array}$ \\
\hline
\end{tabular}

A- Petroleum ether extract, B- 98\% methanolic extract, Tr - Trichophyton rubrum, Tt - Trichophyton tonsurans, Tm- Trichophyton mentagrophytes, Mg- Microsporium gypseum, Ca - Candida albicans, Sa-Staphylococcus aureus, P a- Psudomonas aeruginosa, BsBacillus subtilis, Ec-Escherichia coli, NA-Not Active, K-Ketoconazole, S-Streptomycin Sulphate. 
Table 2- Preliminary Phytochemical screening for secondary metabolites in Solanum nigrum young leaf extracts.

\begin{tabular}{|c|c|c|c|}
\hline $\begin{array}{l}\text { Secondary } \\
\text { metabolites }\end{array}$ & Name of the test & $\mathbf{P E}$ & ME \\
\hline \multirow[t]{4}{*}{ Alkaloids } & Mayers test & ++ & - \\
\hline & Dragendoff's test & + & - \\
\hline & Wagner's test & - & - \\
\hline & Hot water test & - & ++ \\
\hline \multirow[t]{3}{*}{ Phenol } & Ferric chloride test & - & + \\
\hline & Ellagic acid test & + & ++ \\
\hline & Ferric chloride test & - & ++ \\
\hline \multirow[t]{3}{*}{ Flavonoids } & Lead acetate test & - & ++ \\
\hline & Shinoda test & + & ++ \\
\hline & Zinc/ $\mathrm{HCl}$ test & + & + \\
\hline \multirow[t]{2}{*}{ Tannins } & Gelatin test & - & + \\
\hline & Salkowski's test & - & - \\
\hline \multirow[t]{2}{*}{ Triterpenoids } & $\begin{array}{l}\text { Libermann-Burchard } \\
\text { test }\end{array}$ & + & - \\
\hline & Salkowski’s test & - & - \\
\hline Steroids & $\begin{array}{l}\text { Libermann-Burchard } \\
\text { test }\end{array}$ & - & -+ \\
\hline \multirow[t]{2}{*}{ Saponins } & Foam test & - & + \\
\hline & Keller-Killiani test & - & - \\
\hline \multirow[t]{3}{*}{ Glycosides } & Conc. $\mathrm{H}_{2} \mathrm{So}_{4}$ test & - & + \\
\hline & Molisch's test & - & + \\
\hline & Glycoside test & + & - \\
\hline
\end{tabular}

PE: Petroleum ether extract, B- Interpolar methanolic extract + Present, ++ strongly present, -+ moderately present, - absent.

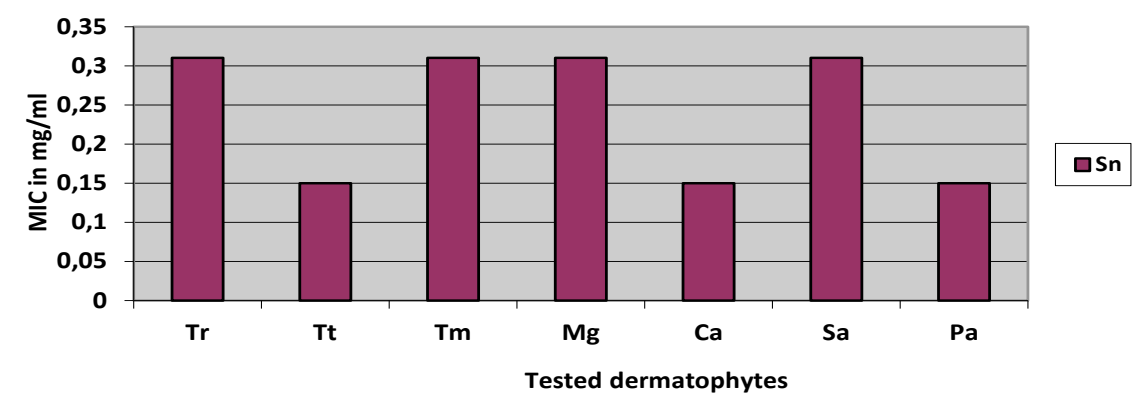

Figure 1- Minimum Inhibitory Concentrations $(\mathrm{mg} / \mathrm{ml})$ of young leaf inter polar extract of S. nigrum.

Sn-Solanum nigrum ,Tr - Trichophyton rubrum, Mg-Microsporium gypseum, Ca - Candida albicans, Tt -Trichophyton tonsurans, Tm -Trichophyton mentagrophytes, Sa-Staphylococcus aureus, BsBacillus subtilis, Ec- Escherichia coli, Pa-Pseudomonas aeruginosa. 


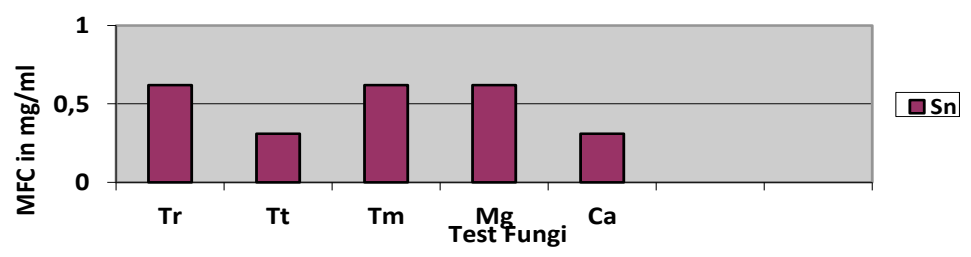

Figure 2-Minimum Fungicidal Concentration $(\mathrm{mg} / \mathrm{ml})$ of young leaf inter polar extract of S. nigrum.

Sn-Solanum nigrum, Tr - Trichophyton rubrum, Mg-Microsporum gypseum, Ca - Candida albicans, Tt -Trichophyton tonsurans, Tm-Trichophyton mentagrophytes.

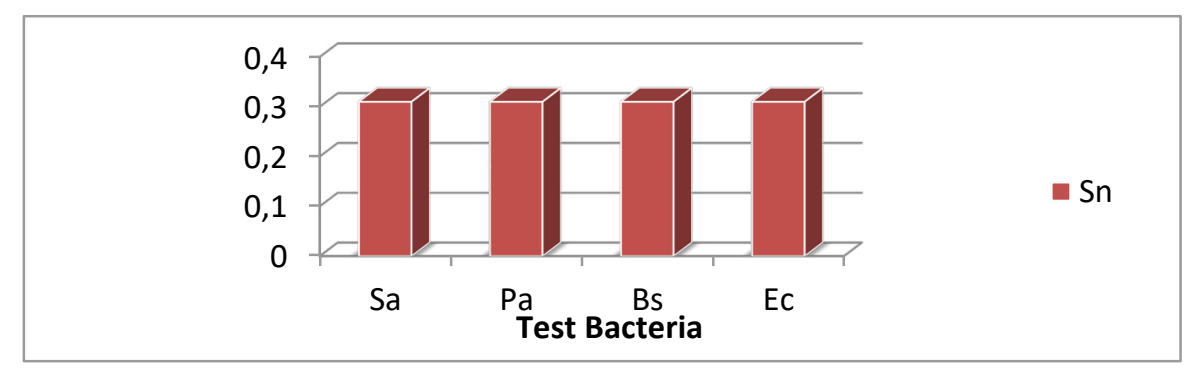

Sn-Solanum nigrum, Sa- Staphylococcus aureus, Bs- Bacillus subtilis, Ec- Escherichia coli, PaPseudomonas aeruginosa.

Figure 3- Minimum Bactericidal Concentration $(\mathrm{mg} / \mathrm{ml})$ of young leaf inter polar extract of $S$. nigrum.

\section{References}

[1] A.V. Krishnaraju, T.V.N. Rao and Sundararaju, Assessment of bioactivity of Indian medicinal plants using Brine shrimp (Alternaria salania) lethality assay, Int. J. Appl. Sci Engg 2 (2005) 125-134.

[2] M.F. Balandrin, A.J. Kjocke, Wurtele et al., Natural plant chemicals sources of industrial and mechanical materials, Science 228 (1985) 1154-160.

[3] J.B. Suffrendini, H.S. Sader, A.G. Goncalves, A.O. Reis, H.L. Gales, A.D. Veralla and R.N. Younes, Screening of antimicrobial extract from plants native to the Brazilian Amazon rain forest and Atlantic forest, Brazil. J. med. Biol. Res 37 (2004) 379-384.

[4] J.S. Evans, E. Pattison, and P. Morris, Antimicrobial agents from plant cell cultures, in Secondary metabolites in plant cell culture. Cambridge University, London (1986) P-12.

[5] S.S. Purohit, and S.K. Mathur, Drugs in Biotechnology Fundamentals and applications. Purohit SS Maximillan publications, India (1999) 576.

[6] S.K. Bhattacharjee, Handbook of Medicinal Plants, 3rd Ed. Pointer Pub. Jaipur (India) 2001 .

[7] A. Jamil, M. Shahid, M.M.H. Khan and M. Ashraf, Screening of some medicinal plants for isolation of antifungal proteins and peptides, Pakistan Journal of Botany 39(1) (2007) 211-221. 
[8] E. Sheeba, Antibacterial Activity of Solanum Surattense Burm. F, Journal of Science, Engineering and Technology 06(1) (2010) 1-4.

[9] Miranda, Vegetacion Chipas. Chiapas, Mexico, Gobiernodel Estado 2 (1976) 47-50.

[10]B. Berlin, E.A. Berlin, D.E. Breedlove, T. Duncan et al. La Herbolaria Medica TzeltalTzotzil en los altos de Chiapas, Chicagas, Mexico, Gobiernodel Estado (1993) 154.

[11]J.W. Rippon, Medical Mycology, The Pathogenic Fungi and the Pathogen Antimycetes, 2nd ed. London, W.B. Saunders (1982)154-248.

[12] G.E. Grabue, Treatment of oral Candida mucositis infections, Drugs (1994) 47, 734-740.

[13]J.M. Edmonds and J.A. Chweya, Black nightshades, Solanum nigrum L. and related 5 species, Inernational Plant Genetic Resources Institute (1997) 1st ed. 1:86.

[14] T. Al-Qirim, M. Syed, S. Moyad, S. Ghassan and B. Naheed, Effect of Solanum nigrum on immobilization stress induced antioxidant defence changes in rat, Research journal of Biological Sciences (3) (2008) 1426-1429.

[15] M. Jainu, C.S.S. Devi, Antiulcerogenic and ulcer healing effects of Solanum nigrum (L.) on experimental ulcer models: Possible mechanism for the inhibition of acid formation, Journal of Laboratory and Clinical Medicine 98 (2005) 417-27.

[16]K.R. Kritikar and B.D. Basu, Indian Medicinal Plants, 2nd ed, Lalit Mohan Basu, Allahabad (1935) 457, 58.

[17] T. Ikeda, H. Tsumagari and T. Nohara, Steroidal oligoglycosides from Solanum nigrum growing in Azerbaijan, Biologicheskie Nauki 3 (1992) 15-8.

[18]J.M. Sashikumar, A. Remyam and K. Janardhanan, Antimicrobial activity of ethno medicinal plants of Nilgiri biosphere reserve and Western Ghats, Asian Journal of Microbiology Biotechnology and Environmental Science 5 (2003) 183-185.

[19]P. Shivakumar Singh and G.M. Vidyasagar, Ethno medicinal plants used in the treatment of skin diseases in Hyderabad Karnataka region, Karnataka, India, Asian Pacific Journal of Tropical Biomedicine 3(11) (2013) 882-886.

[20] S. Magaldi, S. Mata-Essayag, C. Hartung de Capriles, C. Perez, M.T. Colella, Carolina Olaizola and Yudith Ontiveros, Well diffusion for antifungal susceptibility testing, International Journal of Infectious Diseases 8 (2004) 39-45.

[21] National Committee for Clinical Laboratory Standards (NCCLS), Approved Standard M2-A6, 5th ed. NCCLS: Wayne, PA, (1997).

[22]J.B. Horborne, Phytochemical Methods, A Guide to Modern Techniques of Plant Analysis $3^{\text {rd }}$ Eds. Chapman and Hall. London, (1998).

[23] M. Amir and S. Kumar, Possible Industrial application of genus Solanum in twenty first century- A review, Journal of Scientific and Industrial Research 63 (2004) 116-124. 
[24]D. Juneja, P.N. Shrivastava, M.K. Guha and R.C. Saxena, Phytochemical screening of some folklore medicinal plants for their anti-inflammatory activity, Pharmacognosy Magazine 11 (2007), (Suppl), Jul-Sept.

[25] Sweta Prakash and K. Ashok Jain, Antifungal activity and preliminary phytochemical studies of leaf extract of Solanum nigrum Linn., J Pharm Pharm Sci 3(4) (2011) 352355 .

[26]H. Tsuchiya, M. Sato, T. Miyazaki, S. Fujiwara, S. Tanigaki, M. Ohyama, T. Tanaka, M. Iinuma, Comparative study on the antibacterial activity of phytochemical flavanones against methicillinresistant Staphylococcus aureus, Journal of Ethnopharmacology 50 (1996) 27-34.

[27] T.L. Mason, B.P. Wasserman, Inactivation of red beet betaglucan synthase by native and oxidized phenolic compounds, Phytochemistry 26 (1987) 2197-2202.

[28]C. Ya, S.H. Gaffney, T.H. Lilley, E. Haslam, Carbohydrate-polyphenol complexation, In: Hemingway, R.W. and Karchesy, J.J. (ed.). Chemistry and significance of condensed tannins, Plenum Press, New York (1988) 553.

[29] M. Scortichini, M. Pia Rossi, Preliminary in vitro evaluation of the antimicrobial activity of terpenes and terpenoids towards Erwinia amylovora (Burrill) Winslow et al., Journal of Applied Bacteriology, 71 (1991) 109-112.

[30]N. Goren, H. Woerdenbag, C. Bozok-Johansson, Cytotoxic and antibacterial activities of sesquiterpene lactones isolated from Tanacetum praeteritum subsp, praeteritum, Planta Medica 62 (1996) 419-422.

[31]C.G. Barnabas, S. Nagarajan, Antimicrobial activity of flavonoids of some medicinal plants, Fitoterapian 3 (1988) 508-510.

[32] Muhammad Zubair, Komal Rizwan, Nasır Rasool, Nosheen Afshan, Muhammad Shahid, Antimicrobial potential of various extract and fractions of leaves of Solanum nigrum, International Journal of Phytomedicine 3 (2011) 63-67. 